\title{
Suminājums izcilai personībai - Alvīnei Pāvulei
}

\author{
Līga Aberberga-Augškalne
}

2010. gada 2. jūnijā apritēja 100 gadi, kopš dzimusi izcila personība Latvijas fiziologu saimē - Alvīne Anna Pāvule.

Alvīne Pāvule dzimusi Slokas pagasta "Mežbeltēs". Pāvulu giimene: tēvs Pēteris, māte Paulīne (dzimusi Plēcis) - zemkopji; vinuu bērni - meitas Amālija, Emīlija un Alvīne, dēli Jānis un Andrejs. Skolas gaitas Alvīne aizsāk 1919. gadā Slokas pilsētas sešgadīgajā pamatskolā, tad līdz 1929. gadam pēc tam mācās Rīgas Jūrmalas vidusskolā Dubultos, gadu papildinās latīnu valodas kursos un 1930. gadā pèc nokārtotajiem eksāmeniem tiek uzṇemta Latvijas Universitātes (LU) Medicinas fakultātē. Studiju laikā Alvīne iestājas studenšu korporācijā "Daugaviete" (1933. g. II sem. coets), kuras principiem paliek uzticigga visās dzīves gaitās.

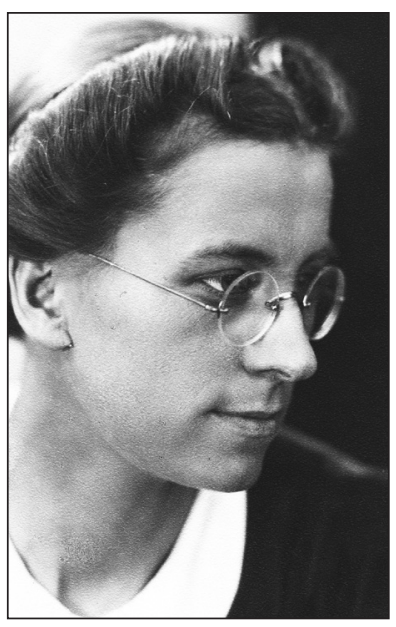
1934. gadā topošā ārste sāk strādāt par volontieri pie profesora J. Miḳelsona Iekškīgo slimību hospitālā katedrā, kur turpina strādāt ar pārtraukumiem līdz 1937. gadam. Studentu zinātnisko darbu konkursā 1935./1936. m. g. Alvīne Pāvule iegūst 2. godalgoto vietu par darbu "Ischias et spondylosis deformans", kas dod iespēju studentu vasaras praksi strādāt Stokholmā. Vairākus mēnešus 1936. gadā viṇa papildina zināšanas klīniskās laboratorijas tehnikās Londonā.

L,oti sekmīgi beigusi Latvijas Universitāti un 1936. gadā ieguvusi ārsta grādu (diploms N151), Alvīne Pāvule uzsāk darba gaitas Rīgas pilsētas 1. slimnīcas laboratorijā, vielmaiņas un elektrokardiogrāfijas kabinetā, turpina volontiera darbu 


\section{Aberberga-Augškalne}

LU Iekškīgo slimību hospitālā katedrā, strādā arī pagaidu darbā par ārsti Latvijas Valsts dzelzceḷa slimnīcā un apgūst serolog̣iskas un mikroḳimiskas klīniskās laboratorijas metodes Stokholmā.

No 1937. gada novembra Alvīne Pāvule uzsāk pedagoǵisko un zinātnisko darbu LU Medicīnas fakultātes Fiziolog̣ijas un fiziolog̣iskās ḳīmijas katedrā (katedras vadītājs profesors R. Krimbergs) par jaunāko asistenti, 1940. gadā strādāja jau par vecāko pasniedzēju līdz 1943. gada septembrim, kad slimības dēl aiziet no darba. Šajā laikā Alvīne Pāvule saraksta darbu "Fiziolog̣iskā ķimija" (172 lpp.). Pēc izveseḷošanās 1944.-1945. gadā strādā par ārsti laboratorijas vadītāju psihiatriskajā slimnīcā "Aleksandra Augstumi".

Otrā pasaules kara beigu posms bija saistīts ar vislielāko un Latvijai neatgūstamo ārstu zaudējumu. Lielus zaudējumus cieta arī Medicīnas fakultāte, kuras kodols būtībā tika iznīcināts (A. Vīksna, 1995). Pēc Rìgas atbrīvošanas 1944. gada oktobrī, Medicīnas fakultātes dekāna uzaicināta, Alvīne Pāvule atgriezās darbā LVU Fiziolog̣ijas un fizioloǵiskās k̦īmijas katedrā kā vecākā lektore. Katedrā viṇa bija vienīgā docētāja apstākḷlos, kad katedras telpas bija izdemolētas, dal̦a aparatūras izvesta, daļa sabojāta, bet decembrī jau varēja uzsākt mācības. Par šo pašaizliedzīgo darba ieguldījumu Alvīne Pāvule 1945. gadā tika apbalvota ar medaḷu "Par godprātīgu darbu 1941-1945". Profesors A. Biezinšš šo laiku raksturo (1960) šādi: ".. latviešu ķirurgi bija izsvaidīti vai iznīcināti. Medicīnas fakultātes 32 katedras sadalija starp trim profesoriem un sešiem docentiem. Profesors P. Stradiņš vadīja 14 visdažādākā profila katedras, profesors J. Miḳelsons vadīja Fiziolog̣ijas, Fizioloǵiskās ķimijas un Hospitālās terapijas katedru.

Alvīne Pāvule organizē medicīnas studentu apmācību fiziologijā un biokīimijā, lasa lekcijas un vada praktiskās nodarbības normālā fiziolog̣ijā un biokīimijā, 1944./1945. m. g. vada Biokīmijas katedru, un jau LVU pirmajā zinātniskajā sesijā 1945. gadā iesniedz tēzes "Kalcija un kālija jonu ietekme uz sirds muskulatūras saraušanos". Profesoru un docētāju kadri 1945. gadā jau bija nokomplektēti, un Medicīnas fakultātē strādāja 7 profesori, 7 docenti un 49 asistenti. Par Fiziologijas katedras vadītāju kluva profesors A. Zubkovs, bet par Bioḳimijas katedras vadītāju - profesors A. Šmits. Savā autobiogrāfijā Alvīne Pāvule raksta, ka kopš 1946. gada strādā Fiziolog̣ijas katedrā par vecāko pasniedzēju. Kopā ar I. Mežuli viņa tulko A. Zubkova lekcijas "Cilvēka fiziologijas kurss". Vienlaikus ar akadēmisko un zinātnisko darbu Alvīne Pāvule sekmīgi pabeidz Marksisma un l̦eṇinisma vakara universitāti (1945-1947).

Nodibinoties Latvijas PSR Zinātṇu akadēmijai, Alvīne Pāvule aktīvi iesaistās zinātniskajā darbā fiziologijas sektorā. Top zinātniskie ziņojumi par paradoksāliem fenomeniem skeleta muskulatūrā (1946), par pārmaiņām ādā pēc īslaicīgas asinsrites - kā jaunākā zinātniskā līdzstrādniece (1946-1948) Bioloǵijas un eksperimentālās medicīnas institūtā pārtraukšanas (1947, tēzes LVU II zinātniskajā sesijā), par asinsvadu nosacijuma refleksiem (1948, rokraksts), par elpošanas pārmaiṇām, izstrādājot sirds un asinsvadu nosacijuma refleksus akūtā eksperimentā 
(1949, tēzes LVU III zinātniskajā sesijā). Alvīnes Pāvules padziḷinātā pētījuma (disertācijas) tematiku" Sirds un asinsvadu nosacỉjuma refleksi uz sapīgiem kairinātājiem" (249 lpp.) zinātṇu kandidāta grāda iegūšanai zināmā mērā noteica pārspīlētā I. Pavlova mācības interpretācija medicīnā pēc 1946. gada. Alvīne Pāvule zinātṇu kandidāta grādu spīdoši aizstāv 1950. gadā, un ir pirmo Latvijas fiziologu vidū (A. Pāvule, A. Krauklis, I. Mežulis), kuri iegūst zinātṇu kandidāta nosaukumu (A. Krauklis, 1972).

1949. gadā katedras vadītāju profesoru A. Zubkovu nomaina profesors N. Daņilovs, kurš 1950. gadā, nodibinoties Rīgas Medicīnas institūtam (RMI), kḷūst par Normālās fiziologijas katedras vadītāju. Vecākā lektore Alvīne Pāvule pilnībā īsteno apmācību fizioloǵijā latviešu plūsmas studentiem, ir atbildīgā par katedras saimniecisko darbu. 1953. gada oktobrī Pāvule tiek ievēlēta par docenti, un Augstākā Atestācijas komisija Maskavā 1954. gada 9. janvārī (protokols Nr. 1) pieškir viņai docenta nosaukumu. Sagatavojusi praktisko darbu aprakstus fizioloǵijā, Pāvule pievēršas pētijumiem balneolog̣ijā (1953, LPSR ZA Vēstis), īpaši Ķemeru dūṇu aplikāciju ietekmei uz sirds un asinsvadu sistēmu $(1954,1955)$, kopā ar I. Mežuli un N. Daņilovu piedalās orǵināla optiska poligrāfa izstrādē, ar kura palīdzību vienlaikus var reǵistrēt dažu artēriju pulsācijas, arteriālo asinsspiedienu un elpošanas kustības. Šà aparāta apraksts tiek publicēts prestižajā PSRS Fizioloǵijas žurnālā (1954). Tā ir pirmā Latvijas fiziologu zinātniskā publikācija Padomju Savienībā. Alvīne Pāvule veic ne tikai pedagoğisko un zinātnisko, bet arī sabiedrisko un izglïtojošo darbu. Liecỉba tam ir viņas sarakstītie darbi "I. Sečenova dzīve" (1955), "Galvas smadzenes un to darbs" (1958), "Daži fiziologijas pamatjēdzieni" (1963), daudzas populārzinātniskās lekcijas.

RMI direktors E. Burtnieks un partijas sekretārs A. Čukalovskis 1955. gadā Pāvuli vērtē kā kvalificētu speciālisti fiziologijā un par labiem rādītājiem mācību un sabiedriskajā darbā izsaka pateicību. Alvīne Pāvule bija daudzu zinātnisko pētỉjumu konsultante un oficiālā oponente, izvērtējot zinātnisko darbu (disertāciju) atbilstību izvirzītajām prasībām A. Dālmanei (1955), J. Šusteram (1958), E. Melkam (1963), J. Baltkājam (1965), J. Liepiņam (1969) u. c.

No 1958. gada 1. septembra Alvīne Pāvule ir Normālās fiziologijas katedras vadītāja vietas izpildītāja, no 1959 . gada 2 . oktobra - katedras vadìtāja, un, vienbalsīgi pārvēlēta 1969. gadā, veic šos pienākumus līdz pat sava mūža pēdējām dienām (1975. gada 30. jūnijs). Pateicību par laba darba ieguldījumu Alvīne Pāvule saṇēma vairākkārt - 1959. gadā (LPSR Veselības Aizsardzības Ministrijas pavēle Nr. 366/12), 1960. gadā (RMI pavēle Nr. 738), 1963. gadā (RMI pavēle Nr. 590) un 1974. gada 12. maijā izvirzìta apbalvojumam "Veselības aizsardzības teicamnieks".

Docentes zinātniskās intereses galvenokārt bija saistītas ar asinsrites reflektorisko regulāciju. Pirmās zinātniskās publikācijas par šo tēmu ir 1954.-1959. gadā, un pēc desmit gadu rūpīga eksperimentālā darba Alvīne Pāvule savā otrajā doktordisertācijā "Apzarṇa asinsvadi kā refleksogēnā zona" (504 lpp.) pamatoja kon- 


\section{Aberberga-Augškalne}

cepciju par vēdera dobuma orgānu asinsvadu būtisko lomu sistēmiskās asinsrites darbības normālā regulācijā, un to spīdoši 1969. gadā aizstāvēja Tartu Universitātē. Vairāk par 50 zinātnisko publikāciju, no tām 35 laikā no 1960. līdz 1971. gadam raksturo skaidru, gana oriǵinālu eksperimentālā pētījuma mērḳa uzstādījumu ar klīnisku ievirzi, precìzu pētījuma metodiku un argumentētus pētijjuma secinājumus. Erudītās fiziolog̣es un lieliskās eksperimentētājas dāsnie padomi un ieteikumi, kā arī dzīvnieku operāciju iemaņas lieti noderēja plašam zinātnieku un klinicistu pulkam: nefrologiem, gastroenterologiem, stomatologiem, veterinārārstiem un katram, kuru interesēja fiziologiija, medicīna. Alvīnes Pāvules vadībā ir sagatavotas vairākas zinātṇu kandidāta disertācijas, viṇa ir bijusi konsultante A. Valtnera doktora disertācijai. Viṇa aktīvi darbojās Fiziologu biedrības Latvijas nodậā, no 1965. gada bija tās priekšsēēetāja. Būdama Populārās medicīnas enciklopēdijas (1975) atbildīgā redaktora vietniece, viṇa ar lielu rūpỉbu un atbildỉbas sajūtu strādāja pie tās sagatavošanas, uzrakstījusi un redigéjusi vairākus desmitus šķirkḷu.

Alvīne Pāvule bija mīlēta un atzīta pedagoǵe. Viṇas perfekti pārdomātās, bagātīgi ilustrētās, ar eleganci lasītās lekcijas un izstrādāto fizioloǵijas programmu ir apguvuši ne vien visi pēckara periodā studējošie, ne tikai 50., 60. un 70. gadu Medicīnas fakultātes absolventi - ārsti, zinātnieki un docētāji, bet arī citi interesenti.

Šo izcilo personību raksturoja augsti attīstīta inteliǵence - spēja uztvert, izprast un novērtēt citu domas, plašas un precīzas zināšanas gan viņas tiešajā specialitātē - fizioloǵijā, gan medicīnà vispār, gan arì citos cilvēka garīgās darbības virzienos - literatūrā, mākslā, mūzikā. Viṇa ar lielu interesi sekoja visiem saviḷnnojumiem sabiedrības dzivē - un to bija ne mazums. Viṇa spēja šis daudzveidīgās gara bagātības sintezēt vienotā koncepcijā, ko viṇa gan necentās ìpaši formulēt, taču tā bija klāt ikvienā sarunā un vērtējumā, lieliskajās zinātniski literārajās esejās, viṇas rīcības izvēlē. Apbrīnojamas bija Alvīnes Pāvules lielās darbaspējas, kas zemnieka meitai ieliktas šūpuli - pamatīgums, pašaizliedzība, nesavtība un darba mīlestība. Nepārtrauktais pedagogíiskais darbs no 1937. gada ar pastāvīgu rūpi par lekciju un praktisko darbu papildināšanu un jauninājumiem, spīdoši aizstāvētas divas disertācijas tik skrupulozajā eksperimentālās fiziologiijas jomā ar klīnisku virzību, vairāk nekā 50 publicētu zinātnisko darbu, pirmā pēckara mācību grāmata 1972. gadā "Cilvēka fiziologiija" (345 lpp.) latviešu valodā, administratīvie un sabiedriskie pienākumi katedrā un Fiziologu biedrībā, populāras lekcijas, raksti, brošūras. Un tas viss - vienmēr teicamā kvalitātē, vienmēr laikā un precīzi. 


\section{Ovation for outstanding personality - Alvīne Pāvule (Summary)}

\section{By Līga Aberberga-Augškalne}

In 2010 it is 100 years since Alvine Anna Pāvule berth. She was outstanding person between Latvian physiologists. She was born in Sloka, in family of farmers, graduated very successfuly from Medical faculty of Latvia University in 1936. She started teaching medical students at 1937, worked as doctor, became professor assistant in 1953, was permanent chief of the Department of Physiology from 1954 till 1975. She was an excellent, intelligent teacher for the students and physiologists, preparing lectures and practicals. A. Pāvule edited the first book in human physiology in Latvian in 1972 and had over 50 scientific articles and reviews in the field of cardiovascular physiology, actively participate in Society of Physiologists in Latvia, was chairman of society from 1965. Her scientific interests were closely tied with cardiovascular physiology, in the hard and precise field of experimental physiology where the practical outcome was related to clinic and she defended two dissertation with great success.

Her life was selfless, accurate and creative labour, always in excelent quality, always in time.

Lìga Aberberga Augškalne, Dr. habil. med., RSU profesore

Dzirciema iela 16, Rīga, LV-1007

Latvia

E-mail: 1.aberberga@apollo.lv 